УДК 37.091:004

Особов Іван Павлович

асистент кафедри педагогіки

Луганський національний університет імені Тараса Шевченка, м. Луганськ, Україна

osobov@gmail.com

\title{
СУЧАСНИЙ ЕТАП ОРГАНІЗАЦІЇ ОСВІТНЬОГО ПРОЦЕСУ З УРАХУВАННЯМ ОСОБЛИВОСТЕЙ ВИКОРИСТАННЯ ІНФОРМАЦЙНО- КОМУНІКАЦІЙНИХ ТЕХНОЛОГІї
}

\begin{abstract}
Анотація. У статті проаналізовано взаємозв'язок, місце та роль поняття «інформаційнокомунікаційні технології» серед понять, пов'язаних з технологією навчання. Автор аналізує аспекти виникнення поняття «Інформаційно-комунікаційні технології», сучасні підходи щодо його визначення. Визначено здатність використання IКТ у навчально-виховному процесі. Подано характеристику засобів ІКТ за способом їх використання в освітньому процесі. У статті розглядаються можливі напрями впровадження засобів IКТ в навчальний процес, аналізується вплив інформаційно-комунікаційних технологій на процес формування сучасного освітнього процесу.
\end{abstract}

Ключові слова: інформаційно-комунікаційні технології; інформаційна технологія; інформаційні технології навчання.

\section{1. ВСТУП}

Постановка проблеми. Аналіз наукових публікацій, а також реальної освітньої практики свідчить, що останнім часом активно проводяться дослідження 3 використання в освітньому середовищі інформаційно-комунікаційних технологій (IКТ) як його комунікативного компонента. Відбувається особливо активне застосування комп'ютерної техніки й упровадження інформаційних технологій в освіту. Такі інноваційні технології, на нашу думку, можуть найбільш ефективно впроваджуватися у вузівський освітній процес. ІКТ самі собою $є$ чинником підвищення мотивації до навчання, що слід враховувати у формуванні сучасного освітнього процесу.

Володіння інформаційно-комунікаційними технологіями (IКT) $\epsilon$ неодмінною умовою професійної компетентності фахівця соціально-гуманітарної сфери діяльності. Сучасна освіта, спрямована на гуманізацію, інформатизацію, медіатизацію педагогічного процесу, враховує необхідність упровадження IКТ в педагогічну практику. Із цими технологіями в умовах вузівського освітнього середовища пов'язують активне сприяння отриманню таких ключових компетенцій як соціальна, комунікативна, інформаційна, когнітивна, спеціальна. Ці технології сприяють широкому застосуванню аналітичних, практичних, експериментальних принципів навчання, орієнтованих на кожного студента.

Незважаючи на значну кількість досліджень, присвячених окремим аспектам інформатизації процесу професійного навчання, потребує уточнення понятійний апарат сучасних освітніх інформаційно-комунікаційних технологій.

Аналіз останніх досліджень. Дослідженню проблем, пов'язаних з використанням інформаційних і комунікаційних технологій на сучасному етапі організації освітнього процесу, присвячено праці багатьох зарубіжних (Г. Рейнгольд, Е. Венгер, І. Захарова, К. Свон; М. В. Моісеєва, С. С. Полат, Н. Ф. Тализіна, А. В. Хуторський, Н. С. Чураєва), і вітчизняних учених (В. П. Беспалько, В. Ю. Биков, В. І. Гриценко, О. М. Довгялло, М. І. Жалдак, М. З. Згуровський, С. П. Кудрявцев, В. Б. Лаврінець, Г. Ю. Маклаков, 
Ю. І. Машбиць, О. В. Співаковський, В. А. Широков, В. Ф. Шолохович, О. М. Спірін, А. М. Гуржій та багато інших).

Стрімке зростання діапазонів використання інформаційних i комунікаційних технологій у світі потребує вдосконалення їх застосування й узгодження термінології, яка наразі виникає. Ці технології надають здатність отримання різноманітної інформації на відстані й необмеженого збільшення кількості учасників навчального процесу, характеру і набору джерел інформації. Набули поширення такі терміни, як «інформаційні технології навчання», «інформаційно-комунікаційні технології навчання», «комп'ютерні технології навчання» та інші. Виникло немало термінів, що характеризують різновиди навчання з їх використанням.

Інформаційні технології навчання належать до педагогічних технологій, що забезпечують оптимальну побудову і реалізацію навчального процесу з урахуванням чітко визначеної дидактичної мети. В. П. Беспалько [1] визначає технологію навчання як «змістовну техніку реалізації навчально-виховного процесу»; Н. Ф. Тализіна вважає, що сучасна технологія навчання полягає у визначенні найбільш раціональних способів досягнення визначених цілей. Що стосується інформаційних технологій навчання (ITH), то існує низка підходів до оцінки їх сутності й місця в освітньому процесі. Так, В. Б. Лаврінець [9] визначає ITH як технології комп'ютерної обробки, передавання, розповсюдження інформації, створення обчислювальних i програмних засобів інформатики. Є. І. Машбиць та Н. Ф. Тализіна розглядають інформаційні технології навчання як деяку сукупність навчальних програм різних типів: від простих програм, що забезпечують контроль знань, до навчальних систем, що базуються на штучному інтелекті. В. Ф. Шолохович [13] пропонує визначати ITH з точки зору їх змісту як галузь дидактики, що займається вивченням планомірно й свідомо організованого процесу навчання і засвоєння знань, де знаходять застосування засоби інформатизації освіти.

Метою статті $є$ уточнення взаємозв'язків поняття «інформаційно-комунікаційні технології» (і відповідного терміну) з поняттями, пов'язаними з технологією навчання, а також визначення ролі ІКТ у професійній підготовці майбутніх фахівців соціальногуманітарної сфери діяльності.

\section{2. МЕТОДИ ДОСЛІДЖЕННЯ}

Під час написання цієї статті ми використовували такі теоретичні методи дослідження: аналіз проблеми у науково-методичній літературі; метод конкретизації для диференціації й уточнення понять «інформаційна технологія», «інформаційні технології навчання», «інформаційно-комунікаційні технології», «комп'ютерні технології навчання».

\section{3. РЕЗУЛЬТАТИ ДОСЛІДЖЕННЯ}

Виклад основного матеріалу дослідження. У матеріалах Інституту розвитку інформаційного суспільства ITH визначаються як «сукупність методів, виробничих процесів i програмно-технічних засобів, інтегрованих 3 метою збору, обробки, зберігання, розповсюдження, відображення та використання інформації в інтересах іiі користувачів» [5].

Характеризуючи інноваційні (креативні) технології (порівняно $з$ традиційними), О. В. Морозов підкреслює, зокрема, що основним елементом навчального процесу стає інформація, і підкреслює відмінність між знанням й інформацією. Специфічність 
креативних технологій визначається так: можливість розвитку здатності студента створювати і витягувати знання з одержуваної інформації, тобто використовувати не тільки готові знання, а й напівфабрикат, яким найчастіше $\epsilon$ інформація [10, с. 281].

У вузівському навчальному посібнику I. Г. Захарової відзначається неоднозначність терміна інформаційна технологія: «в окремих випадках мають на увазі певний науковий напрям, в інших же - конкретний спосіб роботи з інформацією: це i сукупність знань про способи і засоби роботи з інформаційними ресурсами, і спосіб і засоби збору, обробки і передачі інформації для отримання нових відомостей про досліджуваний об'єкт» $[6,12]$. Представляється оптимальним таке визначення ITH, що запропоноване I. Г. Захаровою: «це педагогічна технологія, що використовує спеціальні способи, програмні та технічні засоби (кіно, аудіо- та відеозасоби, комп'ютери, телекомунікаційні мережі) для роботи 3 інформацією» [6, 12]. 3 урахуванням комп'ютерних мереж нерідко вживається термін «комп'ютерна технологія навчання» в тому ж сенсі, що і ITH. На сьогодні вже розроблено багато спеціалізованих комп'ютерних систем, які стосуються навчального процесу.

Термін «інформаційно-комунікаційні технології» (IКТ) знаходимо в такому офіційному виданні, як Закон України "Про основні засади розвитку інформаційного Суспільства в Україні на 2007-2015 роки". То чим саме розрізняються поняття «інформачійно-комунікаційні технології» та «інформачійні технологї»? Звернемося до терміна «комунікація». У соціологічній науці під комунікацією (лат. communicatio повідомлення, передача) мається на увазі смисловий та ідеально-змістовний аспект соціальної взаємодії. Дії, які свідомо орієнтовані на їх смислове сприйняття, називають комунікативними. Основна функція комунікації - досягнення соціальної спільності за збереженні індивідуальності кожного ㄲï елемента [12]. У сучасному світі інформаційні технології використовуються для обробки й розповсюдження такого обсягу інформації, що вони істотно впливають на процеси суспільної комунікації і відповідно отримують нові функціональні можливості, тому постає питання про трансформацію даного терміну. Відповідно з цим деякі автори використовують термін «нові інформаційні технології», під якими розуміють системно організовану послідовність операцій, що виконуються над інформацією з використанням засобів і методів автоматизації. Вважаємо, що в умовах упровадження даних технологій у суспільну комунікацію доцільно називати їх інформаційно-комунікаційними. Інакше кажучи, інформаційнокомунікаційні технології $є$ підвидом інформаційних технологій, які представляють собою їх сучасний розвиток $[8,10]$.

Отже, термін «інформаційно-комунікаційні технології» більш точно, порівняно 3 терміном «інформаційні технології», характеризує потенційні здатності використання комп'ютерної техніки і засобів комунікації в інтересах користувача. Вважаємо оптимальним таке визначення IКТ: ие процеси, методи пошуку, збору, формування, зберігання, обробки, представлення, передавання, розповсюдження інформації та способи здійснення таких прочесів і методів із застосуванням засобів комп'ютерної техніки і засобів комунікації.

Інформаційно-комунікаційні технології відіграють значну роль у житті суспільства, реалізуючи завдання соціальної комунікації, управління, а також $\epsilon$ інноваційними педагогічними технологіями. У системі освіти IКТ застосовуються для створення нових засобів для засвоєння знань (діяльності педагога), сприйняття знань (діяльності учня), оцінювання якості навчання $\mathrm{i}$, безумовно, всебічного розвитку особистості учня в ході навчально-виховного процесу $[6,13]$.

Під засобами IКТ маються на увазі «програмно-апаратні засоби і пристрої, що функціонують на базі мікропроцесорної, обчислювальної техніки, а також сучасні засоби і системи інформаційного обміну, що забезпечують операції по збору, 
продукуванню, накопиченню, зберіганню, обробці, передачі інформації» [3]. I. В. Роберт [11] пропонує характеристику засобів IКТ за способом їх застосування у навчально-освітньому процесі; вони використовуються: як засоби навчання (удосконалюють процес викладання); як інструмент пізнання навколишньої дійсності і самопізнання; як засіб розвитку особистості студента; як об'єкт вивчення в рамках освоєння курсу інформатики; як засіб інформаційно-методичного забезпечення й управління навчально-виховним процесом; як засіб комунікацій; як засіб автоматизації процесів обробки результатів експерименту й управління; як засіб автоматизації процесів контролю, корекції, результатів навчальної діяльності, тестування i психодіагностики; як засіб організації інтелектуального дозвілля.

3 точки зору дидактики, IКТ сприяє розвитку творчих здібностей студентів, робить навчання більш інтенсивним й ефективним за рахунок реалізації здатностей використання мультимедіа навчальних систем до дієвого $\mathrm{i}$ наочного подання навчального матеріалу, забезпечує зворотній зв'язок у процесі навчання, дозволяє індивідуалізувати навчання для максимальної кількості студентів з різними стилями навчання i різними спроможностями сприйняття, посилює міжпредметні зв'язки, забезпечує пошук інформації з різноманітних джерел, створює сприятливу атмосферу для спілкування.

Фахівці в галузі інформаційно-комунікаційних технологій підкреслюють доцільність їх використання до всіх навчальних дисциплін. Уводиться поняття інформаційно-навчальної діяльності: вона заснована на інформаційній взаємодії між студентом і викладачем з використанням IКТ і спрямована на досягнення навчальних цілей.

Підкреслимо, що у визначенні методичних вимог до застосування IКT у навчальному процесі мова йде не про заміну традиційних дидактичних принципів, а про наповнення їх таким змістом, який дозволяє використовувати дидактичні принципи за допомогою ІКТ більш конструктивно i продуктивно. Визнаючи це, фахівці підкреслюють, що найсучасніші технічні засоби слід розглядати як інструментарій, а не джерело культури творчого мислення, професійних умінь і навичок (технологічних, комунікативних та концептуальних), інтелекту індивіда [10, с. 277].

Під час одержання й обробки інформації центральну роль відіграє комп'ютер (смартфон, планшетний комп'ютер та інше), включений у систему телекомунікацій. Робота 3 комп'ютером може допомогти визначати стратегію розв'язання навчальнопізнавальних завдань, сформувати передумови для створення навчальних програм 3 урахуванням реальних науково-виробничих процесів. Наразі стає об'єктом вивчення і сама навчально-пізнавальна діяльність студентів. Загальна культура сучасної людини включає в себе інформаційну культуру, мета якої - освоєння інформаційних технологій загального призначення. Проблемам інформатизації освіти присвячені праці зарубіжних і українських учених С. У. Гончаренка, Р. С. Гуревича, Б. С. Гершунського, О. М. Довгялла, М. І. Жалдака, Г. Кєдровича, Ю. І. Машбиця, І. П. Підласого, Й. А. Ривкінда, Р. Нортона, С. Пейперта, С. О. Сисоєвої, Дж. Хартлі та інших. Справедливо стверджується, що «обов'язковою умовою професійної компетенції в будь-якій предметній області є володіння персональним комп'ютером» [2, с. 60].

Інформаційна грамотність як базовий компонент інформаційної культури є одним 3 критеріїв компетентності сучасного фахівця соціально-гуманітарної сфери діяльності, адже це необхідно для його успішної соціалізації і професійної адаптації. У системі освіти до інформаційної культури відносять передусім «розуміння сутності інформації і iï ролі у виробничих і соціальних процесах; знання, уміння і навички, потрібні вчителю для використання основних складових інформаційної і мультимедійної технології в навчальному процесі; розуміння сутності алгоритмізації, структури даних, уміння 
будувати інформаційні моделі нескладних об'єктів, а також найпростіші програми і алгоритми, спроектовані на професійні потреби вчителя» [4, с. 38]. Важливо підкреслити, що мета застосування ІКТ полягає не в бажанні формалізувати навчальний процес, а в прагненні підвищити якість навчання, у зв'язку з чим широке застосування отримують спеціалізовані засоби IKT, які використовувані для інформаційного моделювання в предметній галузі.

Слід мати на увазі, що в роботах з інформатизації навчання звертається увага й на негативний вплив ІКТ. Так, у посібнику «Використання інформаційних та комунікаційних технологій в системі загальної середньої освіти» наголошується, що у разі опори на засоби інформатизації мова викладача виявляється виключеною, знерухомленою; студент не отримує достатньої практики діалогічного спілкування, формування і формулювання думки на професійній мові [6]. Саме це відзначає і Н. І. Гєндіна, говорячи про дегуманізацію [2, с. 61]. Колосальні обсяги відомостей, що подаються деякими засобами інформатизації, такими як електронні довідники, вебенциклопедії, Інтернет-портали, мультимедійні системи презентації інформації, технологія on-line спілкування Skype в Інтернеті, можуть відволікати увагу в процесі навчання.

Використовуючи засоби ІКТ, необхідно враховувати два можливих напрями впровадження засобів інформатизації в навчальний процес [8, с. 8]. Перше 3 них пов'язано з тим, що засоби ІКТ включаються в навчальний процес як "підтримуючі" засобі в рамках традиційних методів історично сформованої системи освіти 3 метою інтенсифікації навчального процесу, індивідуалізації навчання і часткової автоматизації рутинної роботи, пов'язаної з обліком, вимірюванням й оцінюванням знань учнів. Упровадження засобів IКТ в рамках другого напрямку призводить до зміни змісту освіти, перегляду методів і форм організації навчального процесу, побудови цілісних курсів, заснованих на використанні змістовного наповнення засобів інформатизації в окремих навчальних дисциплінах. Знання, уміння i навички в цьому випадку розглядаються не як мета, а як засіб розвитку особистості майбутнього фахівця соціально-гуманітарної сфери діяльності.

\section{4. ВИСНОВКИ ТА ПЕРСПЕКТИВИ ПОДАЛЬШИХ ДОСЛІДЖЕНЬ}

Результати проведеного дослідження свідчать про те, що в педагогічній науці поки існує багато думок щодо визначення ролі й місця освітніх «інформаційнокомунікаційних технологій» на сучасному етапі організації освітнього процесу. Сьогодні вищі навчальні закладі накопичили певний науково-методичний потенціал щодо впровадження IКТ в освітній процес; їх застосування, як правило, вимагає докорінної переробки традиційних навчальних матеріалів, удосконалення змісту, методів та організаційних форм навчання. Застосування ІКТ у підготовці майбутніх фахівців соціально-гуманітарної сфери діяльності забезпечує якісно новий рівень отримання й узагальнення знань, умінь та навичок, сприяє формуванню фахових компетенцій, динамізує формування креативності. Використання IКТ є виправданим i призводить до підвищення ефективності навчання в тому випадку, якщо навчання в повному обсязі без використання відповідних засобів інформатизації важко або неможливо, тобто якщо дотримується принцип доцільності. Перспективи подальшого дослідження полягають у комплексному аналізі впливу інформаційно-комунікаційних технологій на процес формування креативності у майбутніх фахівців соціальногуманітарної сфери діяльності. 


\title{
СПИСОК ВИКОРИСТАНИХ ДЖЕРЕЛ
}

1. Беспалько В. П. Слагаемые педагогической технологии / В. П. Беспалько. - М. : Педагогика, 1989. - $191 \mathrm{c}$.

2. Гендина Н. И. Информационная культура, творчество и креативность выпускника высшей школы в контексте проблем развития человеческого капитала информационного общества / Гендина Наталья Ивановна. Ч. 2 // Информационное общество. - 2009. —№ 1. - С. 57-63.

3. Гончарова А. Н. Типизация средств современных информационно-коммуникативных технологий по видам информационной деятельности. [Електронний ресурс]. - Режим доступу : http://infostudentam.ru/tipizaciya-sredstv-sovremennyx-informacionno-kommunikativnyx-texnologij-zavidami-informacionnoj-deyatelnosti (13.08.2013). - Заглавие с экрана.

4. Жалдак М. І. Педагогічний потенціал інформатизації навчального процесу та проблеми його розкриття // Комп’ютер у школі та сім’ї. — 1999. — № 2. - С. 37-40.

5. Институт развития информационного обществ. [Электронный ресурс]. - Режим доступу : http://www.iis.ru/el-bib. - Заглавие с экрана.

6. Информационные технологии в образовании : учеб. пособие для вузов / И. Г. Захарова. - [3-е изд., стер.].- М. : Академия, 2007. - 192 с.

7. Использование информационных информационных и коммуникационных технологий в общем и среднем образовании. Разработка Института дистантного образования Российского университета дружбы народов [Электронный ресурс]. - - Режим доступу : http://www.ido.rudn.ru/nfpk/ikt/ikt1.html (10.10.2013). — Заглавие с экрана.

8. Куняев Н. Н. О развитии правового регулирования информационно-коммуникационных технологий // Юридический мир. — 2010. — № 7. — С. 7-13.

9. Лаврінець В. Комп’ютерні технології: впровадження в навчальний процесс / Володимир Лаврінець // Освіта. — 2002. — № 18/19 (20-27 берез.). — С. 10.

10. Морозов А. В. Формирование креативности преподавателя высшей школы в системе непрерывного образования : дисс. ... доктора пед. наук : 13.00.08 / Морозов А. В. - М., 2004. $445 \mathrm{c}$.

11. Роберт И. В., Самойленко П. И. Информационные технологии в науке и образовании. — М., 1998. $-178 \mathrm{c}$.

12. Социология: Энциклопедия / [сост: А. А. Грицанов, В. Л. Абушенко, Г. М. Евелькин, Г. Н. Соколова, О. В. Терещенко]. - Мн. : Книжный Дом, 2003. - 1312 с.

13. Шолохович $\quad$ В. Ф. Дидактические основы информационных технологий обучения в образовательных учреждениях : автореф. дисс. ... доктора пед. наук : 13.00.01 / Шолохович В. Ф. — Екатеринбург, 1995. - 48 с.

Матеріал надійшов до редакиї 18.03 .2014 p.

\section{СОВРЕМЕННЫЙ ЭТАП ОРГАНИЗАЦИИ ОБРАЗОВАТЕЛЬНОГО ПРОЦЕССА С УЧЕТОМ ОСОБЕННОСТЕЙ ИСПОЛЬЗОВАНИЯ ИНФОРМАЦИОННО- КОММУНИКАЦИОННЫХ ТЕХНОЛОГИЙ}

\author{
Особов Иван Павлович \\ ассистент кафедры педагогики \\ Луганский национальный университет имени Тараса Шевченко, г. Луганск, Украина \\ osobov@gmail.com
}

\begin{abstract}
Аннотация. В статье проанализирована роль и место понятия «информационнокоммуникационные технологии» среди понятий, связанных с технологией обучения. Автор анализирует аспекты возникновения понятия «Информационно-коммуникационные технологии», современные подходы к его определению. Определены возможности использования ИКТ применительно к образовательному процессу. Дается характеристика средств ИКТ по способу их применения в образовательном процессе. В статье рассматриваются возможные направления внедрения ИКТ в учебный процесс, анализируются возможности влияния информационно-коммуникационных технологий на процесс формирования современного образовательного процесса.
\end{abstract}


Ключевые слова: информационно-коммуникационные технологии; информационная технология; информационные технологии обучения.

\title{
INFORMATION AND COMMUNICATION TECHNOLOGIES AT THE MODERN STAGE OF EDUCATIONAL PROCESS
}

\author{
Ivan P. Osobov \\ Assistant of the Pedagogy Department \\ Lugansk National Taras Shevchenko University, Lugansk, Ukraine \\ osobov@gmail.com
}

\begin{abstract}
The paper focuses attention on the analysis of the role and place of the concept of "information and communication technologies" among the concepts related to technology training. In the article it is analyzed the aspects of nascence of the concept "Information and communication technologies", modern approaches to its identification. The author shows potential and possibility to use ICT at the modern stage of educational process. The paper analyzes the arsenal of modern information and communication technologies, their importance in the development of the potential of students. There are considered conditions of effective functioning of information and communication technologies in educational process. The author discusses possible directions of implementation of informatization in the educational process.
\end{abstract}

Keywords: information and communication technologies; information technology; information technology training.

\section{REFERENCES (TRANSLATED AND TRANSLITERATED)}

1. Bespalko V. P. Terms of educational technology. — Moscow : High school, 1989. — 191 p. (in Russian).

2. Gendina N. I. Information culture, creativity of high school graduates in the context of the problems of human capital of the development of the information society / N. I. Gendina // Information society. 2009. - № 1. - P. 57-63 (in Russian).

3. Goncharova A. N.. Typing means of modern information and communication technologies by type of information activities [online]. - Available from : http://infostudentam.ru/tipizaciya-sredstvsovremennyx-informacionno-kommunikativnyx-texnologij-za-vidami-informacionnoj-deyatelnosti (13.08.2013) (in Russian).

4. Zhaldak M. I. Educational potential of information learning process and problems of its disclosure // The computer in the school and family. - 1999. - № 2. - P. 37-40 (in Russian).

5. The Institute of the Information Society (IIS) [online]. - Available from : http://www.iis.ru (in Russian).

6. Information technologies in education: Textbook manual for schools / I. G. Zaharova. — Textbook for students of higher educational institutions. - Moscow : IC «Akademia», 2007. — 192 p. (in Russian).

7. Use of information Information and communication technologies in general and secondary education. Development of the Institute of Distance Education of the People's Friendship University of Russia [online]. - Available from : http://www.ido.rudn.ru/nfpk/ikt/ikt1.html (10.10.2013) (in Russian).

8. Kunyaev N. N. About the development of legal regulation in the sphere of use of informationalcommunication technologies // Law and Politics. - 2010. — № 9. - P. 7-13 (in Russian).

9. Lavrinec V. Computer technology: introduction in educational process / V. Lavrinec // Education. 2002. — № 18/19 (20-27 March). — P. 10 (in Ukrainian).

10. Morozov A. V. Teacher's Creativity Formation in High School in the System of the Lifelong Education : dis. ... d-ra ped. nauk : 13.00.08 / A. V. Morozov. — Moscow, 2004. — 445 p. (in Russian).

11. Robert I. V., Samoilenko P. I. Information technologies in science and education: textbook for students of pedagogical higher schools. - Moscow : Publishing house of MGPU/, 1998. - 178 p. (in Russian).

12. Sociology: Encyclopaedia [Text]. / [Compilers: A. A. Gricanov, V. L. Abushenko, G. M. Evelkin, G. N. Sokolova, O. V. Tereshhenko]. — Minsk : Book House, 2003. — 1312 p. (in Russian).

13. Sholokhovich V. F. Didactic principles of information technologies in education in the educational institutions : avtoref. dis. ... d-ra ped. Nauk : 13.00.01 / V. F. Sholokhovich. — Ekaterinburg, 1995. — 48 p. (in Russian). 